\title{
Research Approaches in Applied Linguistics
}

Enfoques de investigación en Lingüística aplicada

Abordagens de pesquisa em linguística aplicada

Jhon Eduardo Mosquera Pérez

Magíster en Didáctica del Inglés Secretaría de Educación Departamental del Huila jhon58745@hotmail.com

\begin{abstract}
The present article offers a review and a short analysis based on the text "Research approaches in applied linguistics" written by Patricia Duff (2010). The just mentioned article constitutes the initial section of the book "The Oxford Handbook of Applied Linguistics" and goes from the pages 1 to 19.
\end{abstract}

Keywords: Applied linguistics, research approaches, qualitative approaches.

\section{Resumen}

El presente artículo ofrece una revisión y un breve análisis basado en el texto "Enfoques de investigación en lingüística aplicada" escrito por Patricia Duff (2010). El artículo mencionado constituye la sección inicial del libro "The Oxford Manual de Lingüística Aplicada" y va desde la pagina 1 a la 19.

Palabras clave: Lingüística aplicada, diálogo de paradigmas, investigación cualitativa. 


\section{Resumo}

Este artigo oferece uma revisão e uma breve análise a partir do texto “Abordagens de pesquisa em linguística aplicada” de Patrícia Duff (2010). $\mathrm{O}$ artigo mencionado constitui a seção de abertura do livro "The Oxford Handbook of Applied Linguistics" e vai das páginas 1 a 19.

Palavras-chave: Linguística aplicada, diálogo paradigmático, investigação qualitativa.

The article "Research approaches in applied linguistics" by Patricia Duff (2010) offers an overview of the most recent contributions to the two research paradigms (quantitative and qualitative). This issue is addressed in an interesting way since from the very beginning the author states that most often people think that these paradigms differ to a large extent to each other. Nonetheless, what is ignored most of the times is that more than differing from each other, the two paradigms are rather associated (Duff, 2010, p. 13). This association of paradigms, according to the author comes to be known as the "paradigm dialog" (Denzin, 2008 as cited in Duff, 2010, p. 13) which is the evolution of the paradigms war that took place decades ago. Mixed methods, for example, is the best exemplification of the association of research paradigms. In Duff's (2010) perspective, qualitative research may require to use from time to time quantitative techniques, and vice versa. This happens in the case study approach, "as case study, which is normally considered as qualitative research, may actually reflect a more positivist approach than an interpretive one" (Duff, 2010, p. 4, 5 ). This supports the argument by Duff who states that "quantitative and qualitative approaches are currently viewed as complementary rather than fundamentally incompatible" (p. 13).

Towards the end of the document, the author progressively starts to consider the possibilities and the impact that technology has had in the research field in AL (applied linguistics). New possibilities regarding data analysis, the documentation of endangered language and the insertion of minority populations are among some of the benefits of using technology (Duff, 2010) In addition, Duff makes an interesting prediction and assures that "future AL research will no doubt continue to be greatly influenced by ongoing technical developments in natural language processing, machine, and other translation systems" (p. 15). 
To sum up, the article offers an interesting overview of the most recent contributions into the research paradigms. This also offers an analysis of the most recent technological developments as we are living now in a globalized world which demands the use of new technologies in almost every field of knowledge. Reading this short text was useful in the sense that it helps the reader understand the most recent contributions as it explores in depth the different approaches within the research paradigms such as the case study, ethnography and narrative research. Additionally, what I more remarkably remember after having finished of reading the article is the word "association", as one normally may tend to think that both paradigms have major differences. However, sometimes, to have better results in terms of research, these can be used interchangeably, taking the best of both.

Having all of the previous elements in mind, one of the conclusions one can arrive at is that in order to have a better comprehension about the combination of these two paradigms, more dedication by academicians so as to have a better comprehension of phenomena that take place globally, nationally and locally is required. Besides, more investigation needs to be carried out within the framework of research itself as a manner to contribute to the further expansion of these research approaches in the context of our country. In view of this, now I present a short analysis based on the elements I have been mentioning until now.

QI (qualitative inquiry) is one of the three dominating paradigms in research. Exploring and studying phenomena is the main axis for the development of QI, different to the quantitative approach which tries to analyze and categorize the world throughout statistical methods and analysis. In this sense, the former has been said to follow an inductive approach (a bottom-up), while the latter has been associated with a deductive methodology (top down). This means that both research processes take place differently. Qualitative researchers formulate a guiding question (s), go to places to observe a reduced sample for a determined period of time (maybe 4, 5, 6 individuals to have a richer panorama of the phenomenon) gather information through at least two data collection instruments and provide an analysis (most of the time, though, we (novice researchers) associate data analysis with the action of starting analysis itself from scratch. In fact, Hills (2007) vividly illustrates what it signifies to do analysis in terms of research (which is something more related to observation, analysis and patterns association in order to 
respect what has been said and shared by participants).

Hence, following principles of the QI paradigm for a research study (or considering oneself a qualitative researcher) implies a deep exploration, categorization and understanding of phenomena (sociocultural/educational) by employing multiple methods for data collection and data analysis (Creswell, 2015, Saldaña, 2011) as well as a a series of rigorous and structured steps. Although at first it appears to be a simplistic definition of what QI implies, in previous years Creswell (2018) himself commented that there are more than 20 approaches to QI (demonstrating this the whole complexity revolving around QI) from which action research, phenomenology, ethnography, narrative inquiry and case study have turned into the five dominant.

Quantitative researchers, on the other hand, formulate a hypothesis (the equivalent to the research question in QI), pick large pieces of data and results are transcribed into numbers. Besides these initial differentiations, QI is characterized by philosophical assumptions that permeate the whole process (Creswell, 2018). The philosophical assumptions I just mentioned help us consider the role of values in the research being conducted (axiology), the process of research itself (methodology), what counts as knowledge/the role of the researcher in what is being studied (epistemology) and the nature of the reality being explored (ontology). It becomes necessary, however, to bear in mind that a correct combination of all of these elements would also assure a high level of reliability and trustworthiness in the research study being conducted (Creswell, 2015) as illustrated in Duff (2010) and as reinforced by authors such as Creswell (2018) and Denzin and Lincoln (2008). Another really important aspect to take into consideration is that more recent research trends such as postcolonial / poststructural / emancipatory pedagogies (Flick, 2014) have opened up new opportunities to create more equitable/fair conditions for individuals through research itself (Ndimande, 2012). All of these elements have made the world more interesting and diverse, and we as future researchers must be aware of all what it implies for our field and for the field of education in general.

\section{Referencias}

Creswell, J. W. (2015). 30 essential skills for the qualitative researcher. SAGE Publications.

Creswell, J. W. (2018). Qualitative inquiry and research design: Choosing among five approaches. SAGE. 
Denzin, N. K., \& Lincoln, Y. S. (2008). The landscape of qualitative research. SAGE.

Duff, P. (2010) Research approaches in Applied Linguistics. In R. Kaplan (ed). The Oxford Handbook of Applied Linguistics (2 ed.) (p.119). Oxford: Oxford university Press.

https://doi.org/10.1093/oxford hb/9780195384253.013.0003

Flick, U. (2014). An introduction to qualitative research. SAGE

Hill, L. H. (2007). Thoughts for students considering becoming qualitative researchers Qualities of qualitative researchers. Qualitative

Research Journal, 7(1), 2631. https://doi.org/10.3316/qrj 0701026

Ndimande, B. S. (2012). Decolonizing research in Postapartheid South Africa. Qualitative Inquiry, 18(3), 215226. https://doi.org/10.1177/1 077800411431557

Saldaña, J. (2011). Fundamentals of qualitative research. Oxford University Press. 